ISSN 1678-3921

Journal homepage: www.embrapa.br/pab

For manuscript submission and journal contents, access: www.scielo.br/pab
Helio Tonini $(1 \otimes)(D$,

Marina Moura Morales(2) (iD,

Ciro Augusto de Souza Magalhaes ${ }^{(3)}$ (iD

and Vanderley Porfirio da Silva ${ }^{(2)}$ (iD

(1) Embrapa Pecuária Sul, Rodovia BR-153, Km 632,9, Vila Industrial, Caixa Postal 242, CEP 96401-970 Bagé, RS, Brazil.

E-mail: helio.tonini@embrapa.br

(2) Embrapa Florestas, Estrada da Ribeira, Km 111, Guaraituba, Caixa Postal 319 CEP 83411-000 Colombo, PR, Brazil. E-mail: marina.morales@embrapa.br, vanderlei.porfirio@embrapa.br

(3) Embrapa Agrossilvipastoril, Rodovia dos Pioneiros MT-222, Km 2,5, Zona Rural, Caixa Postal 343, CEP 78550-970 Sinop, MT, Brazil.

E-mail: Ciro.magalhaes@embrapa.br

$\bowtie$ Corresponding author

Received

May 03, 2021

Accepted

May 28, 2021

How to cite

TONINI, H.; MORALES, M.M.; MAGALHÃES,

C.A. de S.; SILVA, V.P. da. Increment in eucalyptus diameter as affected by seasonality and production system. Pesquisa Agropecuária Brasileira, v.56, e02544, 2021. DOI: https://doi.org/10.1590/S1678-3921. pab2021.v56.02544.

\section{Increment in eucalyptus diameter as affected by seasonality and production system}

\begin{abstract}
The objective of this work was to assess the current monthly increment in diameter of eucalyptus (Eucalyptus grandis x Eucalyptus urophylla) trees in response to different production systems, climatic factors, and thinning. The trees were evaluated in four production systems: monoculture and crop-forestry, livestock-forestry, and crop-livestock-forestry integration. The increment in diameter of 80 trees was measured monthly from May 2015 to May 2019. The effect of the climatic variables was determined through correlation and multiple regression analyses. The increment in current monthly diameter is seasonal and highly dependent on accumulated rainfall. The adopted modeling allowed concluding that both water shortage and excess ( 30 and $475 \mathrm{~mm}$ per month, respectively) decreased tree growth in diameter. The trees in the integrated systems showed a higher growth in diameter than those under monoculture, and intercropping with crops resulted in a greater diameter growth than that with pasture. Thinning accelerates the growth of the remaining trees, with an effect of higher magnitude and longer duration in the integrated production systems.
\end{abstract}

Index terms: climate effect, integrated crop-livestock-forestry system, modeling, thinning.

\section{Incremento diamétrico do eucalipto em função da sazonalidade e do sistema de produção}

Resumo-O objetivo deste trabalho foi avaliar o incremento corrente mensal em diâmetro de árvores de eucalipto (Eucalyptus grandis x Eucalyptus urophylla) em resposta a diferentes sistemas de produção, fatores climáticos e desbaste. As árvores foram avaliadas em quatro sistemas de produção: monocultivo e integração lavoura-floresta, pecuária-floresta e lavoura-pecuária-floresta. $\mathrm{O}$ incremento em diâmetro de 80 árvores foi avaliado mensalmente de maio de 2015 a maio de 2019. O efeito das variáveis climáticas foi determinado pelas análises de correlação e regressão múltipla. O incremento corrente mensal em diâmetro é sazonal e altamente dependente da precipitação. A modelagem adotada permitiu concluir que tanto a falta quanto o excesso de água (30 e $475 \mathrm{~mm}$ por mês, respectivamente) reduziram o crescimento das árvores em diâmetro. As árvores nos sistemas de integração crescem mais do que as em monocultivo, e o consórcio com a lavoura resultou em maior crescimento em diâmetro do que o com a pastagem. $\mathrm{O}$ desbaste promove a aceleração no crescimento das árvores remanescentes, com efeito de maior magnitude $\mathrm{e}$ duração nos sistemas integrados de produção.

Termos para indexação: efeito do clima, sistema de integração lavoura-pecuária-floresta, modelagem, desbaste. 


\section{Introduction}

In the past ten years, the area occupied by integrated crop-livestock-forestry (CLF) systems in Brazil increased by 10 million hectares, reaching the current 11.5 million hectares (ILPF em números, 2016). The silvopastoral, agroforestry, and agrosilvopastoral systems account for $17 \%$ or for approximately 2 million hectares of the CLF area (ILPF em números, 2016), which is significant since 9 million hectares are planted with forests in the country (IBÁ, 2020).

The interaction between site factors and growth is well known for some forest species in Brazil, mainly eucalyptus (Eucalyptus spp.) (Gonçalves et al., 2013), whose genus accounts for the most planted species, covering $77 \%$ of the total area used for forest plantations (IBÁ, 2020). Despite this, studies on the monthly vegetative growth of eucalyptus are still scarce (Sette Junior et al., 2012; Castro et al., 2017).

To understand the reaction of trees to short-term changes in environmental conditions, it is crucial to continuously monitor stem radial variations throughout the year (Deslauriers et al., 2007). These variations allow assessing growth based on seasonality and its association with both climatic conditions and effects of silvicultural treatments (Sette Junior et al., 2012).

A lower tree density associated with positive environmental interactions, such as a greater soil fertility and moisture (Assis et al., 2015; Castro et al., 2017), for example, promotes eucalyptus growth in diameter in the CFL system, when compared with monocultures (Paula et al., 2013; Oliveira et al., 2015; Tonini et al., 2019a). However, little is known about the effects of the interaction among agricultural and pasture cultivation, silvicultural treatments, and climatic variations on tree growth in a same site.

In Brazil, the interactions between fertilizer application and thinning in forestry are also underexamined (Castro et al., 2017; Ferraz Filho et al., 2018). These management practices are often applied simultaneously in CLF, since trees can take advantage of the fertilization applied to agricultural crops (Franchini et al., 2014; Mugunga et al., 2017). The fertilization procedure accelerates plant growth and potentiates the thinning effect on the diameter of dominant trees, which is more significant in rich sites (Pretzsch, 2020).

Thinning is used to allow a greater light entry, to reduce intra- and interspecific competition, and to redistribute growth potential in CLF, so that timber yield, quality, and economic return are optimized (Tonini et al., 2019b). Thinning also reduces stand leaf area, rainfall interception, and stand transpiration, improving water availability for the remaining trees and, consequently, reducing forest water use and drought stress (Forrester et al., 2012). These outcomes can be important for regions facing high rainfall seasonality, such as the northern region of the state of Mato Grosso, Brazil.

The objective of this work was to assess the current monthly increment in diameter of eucalyptus (Eucalyptus grandis $\mathrm{x}$ Eucalyptus urophylla) trees in response to different production systems, climatic factors, and thinning.

\section{Materials and Methods}

The experiment was carried out at Embrapa Agrossilvipastoril, located in the municipality of

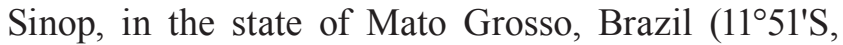
$55^{\circ} 35^{\prime} \mathrm{W}$, at an altitude of $370 \mathrm{~m}$ ), in the Amazon biome. According to Köppen's classification, the climate of the experimental site is a tropical savanna, of the Aw type (Souza et al., 2013). The soil is classified as a Latossolo Vermelho-Amarelo distrófico (Viana et al., 2015), i.e., a typical dystrophic Hapludox (Soil Survey Staff, 2014).

Mean annual rainfall in the north of the state of Mato Grosso can reach values higher than 2,750 $\mathrm{mm}$, with an irregular spatial and temporal distribution. Maximum values are recorded in summer (rainy season), mainly from January to March, when rainfall ranges from 45 to $55 \%$ of the total annual rainfall. Winter (dry season) is extremely dry, with scarce rain events that last four to five days in June, July, and August, when very low totals between 20 and $80 \mathrm{~mm}$ are observed (Souza et al., 2013).

The experiment was installed in October 2011, aiming at assessing four production systems: forest monoculture and livestock-forestry, crop-forestry, and crop-livestock-forestry integration. The Eucalyptus grandis W.Hill ex Maiden x Eucalyptus urophylla S.T.Blake hybrid clone (H13) was the selected forest component. In the monoculture, the trees were planted at $3.5 \times 3.0 \mathrm{~m}$ from each other, totaling 952 trees per hectare. Under the integrated systems, the trees were planted in triple rows in the east-west solar orientation, at a spacing of $3.5 \times 3.0 \times 30 \mathrm{~m}$, with 270 trees per hectare. 
The experiment covered 72 ha in a randomized complete block design, with four replicates. Sample units of 1 and 2 ha were set for monocultures in the integrated systems. Further details about the experiment can be found in Magalhães et al. (2019).

The following treatments were assessed: forest monoculture (F), which consisted of eucalyptus planted at a density of 952 trees per hectare; croplivestock-forestry integration (CLF), eucalyptus trees and soybean [Glycine $\max$ (L.) Merr.] planted from October to February, corn (Zea mays L.) planted from February to July, and 'Marandu' palisade grass [Urochloa brizantha (A.Rich.) R.D.Webster] grazed by Nellore cattle from July to September; livestockforestry integration (LF), eucalyptus and palisade grass grazed by Nellore cattle; and crop-forestry integration (CF), soybean and off-season corn planted between eucalyptus rows.

Soil preparation consisted of subsoiling at $60 \mathrm{~cm}$, furrowing, and fertilization with $70 \mathrm{~kg} \mathrm{ha}{ }^{-1} \mathrm{P}_{2} \mathrm{O}_{5}$. Three cover fertilizations were conducted at: one and two months after tree planting (addition of $20 \mathrm{~kg} \mathrm{ha}^{-1}$ $\mathrm{N}$ and $\mathrm{K}_{2} \mathrm{O}$ ) and one year after planting (addition of 80, 20 , and $80 \mathrm{~kg} \mathrm{ha}^{-1} \mathrm{~N}, \mathrm{P}_{2} \mathrm{O}_{5}$, and $\mathrm{K}_{2} \mathrm{O}$ - mechanically applied in a continuous fillet on the ground).

The soybean crop was fertilized with $80 \mathrm{~kg} \mathrm{ha}^{-1} \mathrm{P}_{2} \mathrm{O}_{5}$ and $\mathrm{K}_{2} \mathrm{O}$, in the $2014 / 2015$ and 2015/2016 crops. This formulation was added with liming $\left(1,000 \mathrm{~kg} \mathrm{ha}^{-1}\right)$ in the 2014/2015 crop, with $100 \mathrm{~kg} \mathrm{ha}^{-1} \mathrm{~K}_{2} \mathrm{O}$ in the 2016/2017 crop, with $120 \mathrm{~kg} \mathrm{ha}^{-1} \mathrm{~K}_{2} \mathrm{O}$ in the 2017/2018 crop, and with $100 \mathrm{~kg} \mathrm{ha}^{-1} \mathrm{~K}_{2} \mathrm{O}$ in the 2018/2019 crop.

The corn crop fertilization was carried out with: 14, 100, and $56 \mathrm{~kg} \mathrm{ha}^{-1} \mathrm{~N}, \mathrm{P}_{2} \mathrm{O}_{5}$, and $\mathrm{K}_{2} \mathrm{O}$ added with $100 \mathrm{~kg} \mathrm{ha}^{-1} \mathrm{~N}$ in the 2014/2015 crop; 14, 100, and 56 $\mathrm{kg} \mathrm{ha}^{-1} \mathrm{~N}, \mathrm{P}_{2} \mathrm{O}_{5}$, and $\mathrm{K}_{2} \mathrm{O}$ added with $66 \mathrm{~kg} \mathrm{ha}^{-1} \mathrm{~N}$ in the 2015/2016 crop; 35, 60, and $60 \mathrm{~kg} \mathrm{ha}^{-1} \mathrm{~N}, \mathrm{P}_{2} \mathrm{O}_{5}$, and $\mathrm{K}_{2} \mathrm{O}$ added with $66 \mathrm{~kg} \mathrm{ha}^{-1} \mathrm{~N}$ in the 2016/2017 crop; 20, 50, and $50 \mathrm{~kg} \mathrm{ha}^{-1} \mathrm{~N}, \mathrm{P}_{2} \mathrm{O}_{5}$, and $\mathrm{K}_{2} \mathrm{O}$ added with $60 \mathrm{~kg} \mathrm{ha}^{-1}$ $\mathrm{K}_{2} \mathrm{O}$ and with $88 \mathrm{~kg} \mathrm{ha}^{-1} \mathrm{~N}$ in the 2017/2018 crop; and 30,80 , and $80 \mathrm{~kg} \mathrm{ha}^{-1} \mathrm{~N}, \mathrm{P}_{2} \mathrm{O}_{5}$, and $\mathrm{K}_{2} \mathrm{O}$ added with 128 and $80 \mathrm{~kg} \mathrm{ha}^{-1} \mathrm{~N}$ in the 2018/2019 crop.

The pasture was fertilized using: $50 \mathrm{~kg} \mathrm{ha}^{-1} \mathrm{~N}$ added with $50 \mathrm{~kg} \mathrm{ha}^{-1} \mathrm{~K}_{2} \mathrm{O}$ and with $40 \mathrm{~kg} \mathrm{ha}^{-1} \mathrm{P}_{2} \mathrm{O}_{5}$ in the 2015/2016 crop; $100 \mathrm{~kg} \mathrm{ha}^{-1} \mathrm{~N}$ added with $100 \mathrm{~kg} \mathrm{ha}^{-1}$ $\mathrm{K}_{2} \mathrm{O}$ and with $80 \mathrm{~kg} \mathrm{ha}^{-1} \mathrm{P}_{2} \mathrm{O}_{5}$ in the 2016/2017 crop; and $50 \mathrm{~kg} \mathrm{ha}^{-1} \mathrm{~N}$ added with $50 \mathrm{~kg} \mathrm{ha}^{-1} \mathrm{~K}_{2} \mathrm{O}$ and with $80 \mathrm{~kg} \mathrm{ha}^{-1} \mathrm{P}_{2} \mathrm{O}_{5}$ in the 2017/2018 crop.
Thinning was performed in August 2016, by selectively removing $45 \%$ of smaller-diameter trees at breast height - approximately 37 to $41 \%$ of the basal area. On average, 374 trees per hectare $\left(6.18 \mathrm{~m}^{2} \mathrm{ha}^{-1}\right)$ were removed in the $\mathrm{F}$ treatment and 111 trees per hectare $\left(2.1 \mathrm{~m}^{2} \mathrm{ha}^{-1}\right)$ in the CLF treatment.

Sites that were not subjected to thinning were used to assess the thinning effect on both current monthly increment in diameter (CMI) and accumulated increments in diameter in the F, CF, and LF treatments; CLF was not evaluated due to a wild fire that happened in 2016, affecting the trees in this location. The evaluated treatments consisted of $346.5 \mathrm{~m}^{2}$ sample units of 30 plants each, installed at the end of the rows, with three more treatments being included in the experiment, namely: $\mathrm{F}_{\text {unthinned, }} \mathrm{CF}_{\text {unthinned, }}$, and $\mathrm{LF}_{\text {unthinned }}$.

Eighty trees were assessed throughout the experiment. Those with a medium diameter were measured on a monthly basis, from May 2015 to May 2019, with the aid of diametric tapes installed at diameter breast height - these features were defined in the previous forest inventory. Tortuous trees or the ones presenting any other abnormality, such as trunk deformities, knots, canker or damage caused by animals, were excluded from the selection.

Thirty-six trees were selected (12 per treatment) for CLF, LF, and CF, based on their position in the planting row and consequent exposure to sunlight - four trees were positioned to the north, four to the south, and four at the center of the rows. A total of 20 trees were selected (ten per treatment) for $\mathrm{F}$ and $\mathrm{F}_{\text {unthinned, }}$, besides 12 trees for $\mathrm{CF}_{\text {unthinned }}$ and $\mathrm{LF}_{\text {unthinned }}$.

Four treatments (F, CF, LF, and CLF), with ten replicates (trees) each, were evaluated to measure the effect of different production systems on CMI.

Trees positioned to the north, south, and center of the planting row were considered treatments, with 16 replicates (trees) each. They were used to assess differences in CMI due to exposure to sunlight, based on tree position in the row. The $\mathrm{F}$ and $\mathrm{F}_{\text {unthinned, }}$ $\mathrm{LF}$ and $\mathrm{LF}_{\text {unthinned, }}$ and $\mathrm{CF}$ and $\mathrm{CF}_{\text {unthinned }}$ treatments were compared to evaluate thinning effects on tree growth. Data collection started in December 2016 (three months after thinning) and ended in May 2019. Comparisons were performed through Student's T-test, at $5 \%$ probability.

CMI was obtained by dividing the circumference increment by 3,141593 , and data were subjected to the 
analysis of variance (ANOVA), based on a completely randomized design. Only trees located in one of the experimental blocks were selected, and each tree stood as one replicate. This selection ensured in genetic, site conditions, and thinning execution-time uniformity.

ANOVA adoption conditions, such as homogeneous variance and residual normality, were assessed through Bartlett's and Shapiro-Wilk's tests, respectively, in the Rbio software (Bhering, 2017). The values of CMI, based on season and year, were compared through Tukey's test, at $5 \%$ probability.

Curves plotted for monthly increment in diameter were fitted through multiple regression analysis, using the stepwise method (Draper \& Smith, 1998), in order to assess the effect of climatic variables. Pearson's correlation was used to assess the association between CMI and the climatic data provided by the weather station installed at the experimental field of Embrapa Agrossilvopastoril. The obtained correlations were used to select model predictors.

The following independent variables were recorded 15,30 , and 45 days before data collection: accumulated rainfall $(\mathrm{mm})$; mean, mean maximum, and mean minimum temperatures $\left({ }^{\circ} \mathrm{C}\right)$; relative humidity (in percentage); global solar radiation (in $\mathrm{MJ}^{2}$ per day); and mean wind speed $\left(\mathrm{km} \mathrm{h}^{-1}\right)$. The climatic variables were tested based on their original, quadratic, logarithmic, and inverse values. This allowed to better understand the delay between the occurrence of climatic variables and tree physiological response measured in CMI (Sette Junior et al., 2012).

The adjusted coefficient of determination, standard error of the estimate (in percentage), significance of coefficients by the T-test and of models by the F-test, and the residual distribution analysis were the support statistics for model selection. The general model was fitted by planting system and assessed through the model identity test, based on the methodology of Regazzi (1999).

\section{Results and Discussion}

The CMI curves presented the same pattern in all treatments, namely: increased growth during the rainy season and a reduced one in the dry season. The highest values were recorded between February and March, with a mean CMI value of $2.7 \mathrm{~mm}$, reducing to a mean value of $0.5 \mathrm{~mm}$ when rainfall started to decrease in May (Figure 1).
According to Drew et al. (2009), Sette Junior et al. (2012), and Castro et al. (2017), there is a strong seasonality in the daily or monthly increment in the diameter of eucalyptus trees subjected to different edaphoclimatic conditions. In hybrids of E. grandis $\mathrm{x}$ E. urophylla, growth has an intermittent pattern, stopping under dry conditions and quickly resuming under water availability (Drew et al., 2009), which was evident in the present study, since $85.1 \%$ of growth in diameter was observed in the rainy season.

Based on the performed Bartlett's $\left(\mathrm{K}^{2}{ }_{(3)}=0.24\right.$; $0.97)$ and Shapiro-Wilk's ( $\mathrm{W}=0.95,0.07)$ tests, there were residuals in variance homogeneity and normal distribution in every production system.

The CLF system did not show any significant difference in the first two rainy seasons in 2015/20162016/2017; however, the obtained results were higher than those for $\mathrm{F}$ in all evaluated periods (Table 1). The diameter increment recorded in CLF was of $1.7 \mathrm{~mm}$, greater than that of $1.0 \mathrm{~mm}$ in $\mathrm{LF}$ and $\mathrm{F}$ in the subsequent rainy seasons. Moreover, only CLF differed from $\mathrm{F}$ in all assessed periods during the dry season.

Gains in monthly diameter increment during the dry and rainy seasons were observed in: CFL, compared with LF and F; and CF, compared with F. This resulted in higher accumulated diameter increments of 97.6 and $107.0 \mathrm{~mm}$, respectively, in the CLF and CF systems (Figure $2 \mathrm{~A}$ ). Growth was greater and lasted longer in the intercropping with trees, soybean, and corn than in that with palisade grass (Figure 2 A). This may have been a result of the interactions between the types of fertilization applied to the crops. Potassium applications can considerably increase water use efficiency by eucalyptus, being a critical factor to boost tree yield in regions subjected to water shortage (Gonçalves et al., 2013).

Research conducted in CLF with soybean, corn, palisade grass, and eucalyptus showed a strong reduction in agricultural yield in zones close to the eucalyptus rows (Franchini et al., 2014; Mugunga et al., 2017). This finding points towards a strong intraspecific competition between crop and forest.

In addition, the availability of a large amount of organic waste, which is constantly renewed by the trees, led to an increase in carbon, organic matter, and $\mathrm{N}$ levels in the soil in the CLF system (Matos et al., 2019). Soybean has a high $N$ content in biomass and a low C:N ratio, producing a fast-decomposition straw, 
which makes $\mathrm{N}$ more abundant for subsequent crops and trees (Gazolla et al., 2015).

The CFL system can improve soil conditions by increasing organic matter levels, biological activity, nutrient amount and availability in the root absorption zone of intercropped crops, and land yield potential (Castro et al., 2017). Assumingly, these features resulted in a CMI that was $31.2 \%$ higher in the integrated production systems, compared with monoculture.
There was a statistical difference in CMI for trees positioned to the north and south of the rows in the 2016/2017 and 2017/2018 rainy seasons; however, both positions promoted a higher diameter increment than the center position in the 2016 and 2018 dry seasons (Table 2). Trees located in the center of the rows grew less than those located on its sides (Figure 2 B), but they grew more than those planted in monoculture under a rainfall of $80.8 \mathrm{~mm}$, within 48 months $(\mathrm{p}<0.01)$.

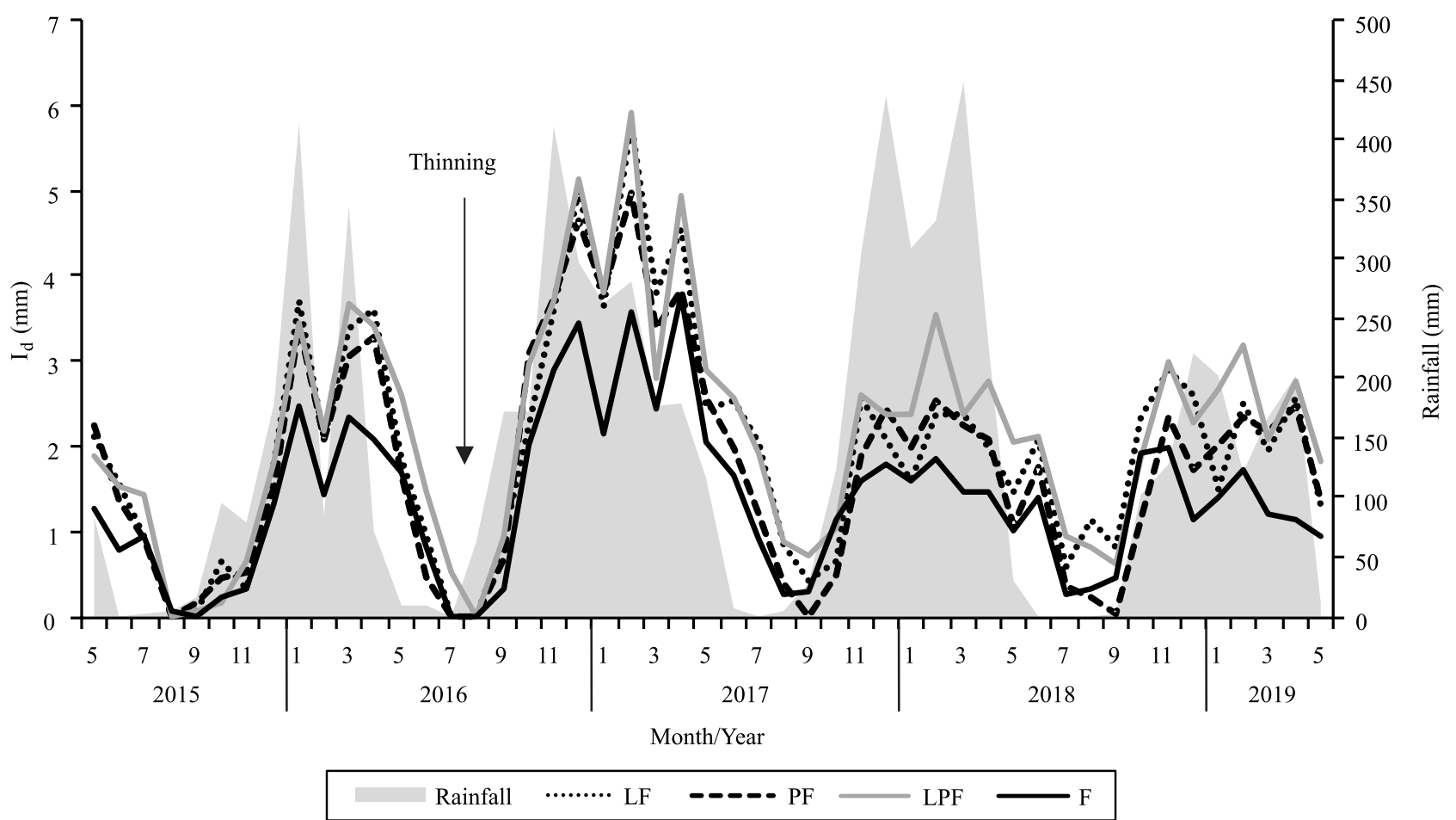

Figure 1. Seasonality of current monthly increment in diameter (CMI) of eucalyptus (Eucalyptus grandis x Eucalyptus urophylla) trees under different production systems: CF, crop-forestry; LF, livestock-forestry; CLF, crop-livestock-forestry; and $\mathrm{F}$, forest monoculture.

Table 1. Mean monthly increment in diameter $(\mathrm{mm})$ of eucalypts (Eucalyptus grandis x Eucalyptus urophylla) trees based on production system and season ${ }^{(1)}$.

\begin{tabular}{lccccc}
\hline Year & Season $^{(2)}$ & \multicolumn{4}{c}{ Mean \pm standard deviation of monthly increment in diameter $(\mathrm{mm})$} \\
\cline { 3 - 5 } & & CLF & CF & LF & $0.8 \mathrm{a} \pm 0.23$ \\
\hline 2015 & Dry & $0.8 \mathrm{a} \pm 0.21$ & $0.8 \mathrm{a} \pm 0.36$ & $2.3 \mathrm{a} \pm 0.61$ & $0.7 \mathrm{a} \pm 0.33$ \\
$2015 / 2016$ & Rainy & $2.5 \mathrm{a} \pm 0.43$ & $2.5 \mathrm{a} \pm 0.46$ & $0.9 \mathrm{a} \pm 0.43$ & $1.7 \mathrm{~b} \pm 0.85$ \\
2016 & Dry & $1.4 \mathrm{a} \pm 0.56$ & $0.9 \mathrm{a} \pm 0.35$ & $3.6 \mathrm{a} \pm 0.78$ & $1.0 \mathrm{a} \pm 0.57$ \\
$2016 / 2017$ & Rainy & $4.3 \mathrm{a} \pm 0.44$ & $4.4 \mathrm{a} \pm 0.44$ & $1.0 \mathrm{~b} \pm 0.66$ & $2.8 \mathrm{~b} \pm 0.92$ \\
2017 & Dry & $1.7 \mathrm{a} \pm 0.29$ & $1.5 \mathrm{ab} \pm 0.43$ & $2.1 \mathrm{~b} \pm 0.37$ & $1.0 \mathrm{~b} \pm 0.22$ \\
$2017 / 2018$ & Rainy & $2.4 \mathrm{a} \pm 0.58$ & $2.1 \mathrm{ab} \pm 0.51$ & $0.8 \mathrm{bc} \pm 0.19$ & $0.7 \mathrm{c} \pm 0.27$ \\
2018 & Dry & $1.4 \mathrm{a} \pm 0.43$ & $1.2 \mathrm{ab} \pm 0.37$ & $2.2 \mathrm{~b} \pm 0.32$ & $1.3 \mathrm{c} \pm 0.33$ \\
$2018 / 2019$ & Rainy & $2.6 \mathrm{a} \pm 0.40$ & $2.2 \mathrm{ab} \pm 0.42$ & $\mathrm{c}$ & \\
\hline
\end{tabular}

${ }^{(1)}$ Means followed by equal letters, in the rows, do not differ from each other by Tukey's test, at $5 \%$ probability. ${ }^{(2)}$ Dry, dry season from June to August; and Rainy, rainy season from September to May. ${ }^{(3)}$ Production systems: CLF, crop-livestock-forestry; CF, crop-forestry; LF, livestock-forestry; and F, forest monoculture. 
Trees in the upright position receive a large amount of light throughout the vertical extension of their crown, developing more vigorous branches from the lowest part of the stem and, consequently, a larger diameter from the lowest portion of the trunk (Martins et al., 2000). However, trees in the central position have to compete for water, light, and nutrients at rates closer to those observed for monocultures (Tonini et al., 2019a).

The increment in the diameter of eucalyptus trees is highly responsive to climatic conditions, spacing, and silvicultural treatments, such as thinning and
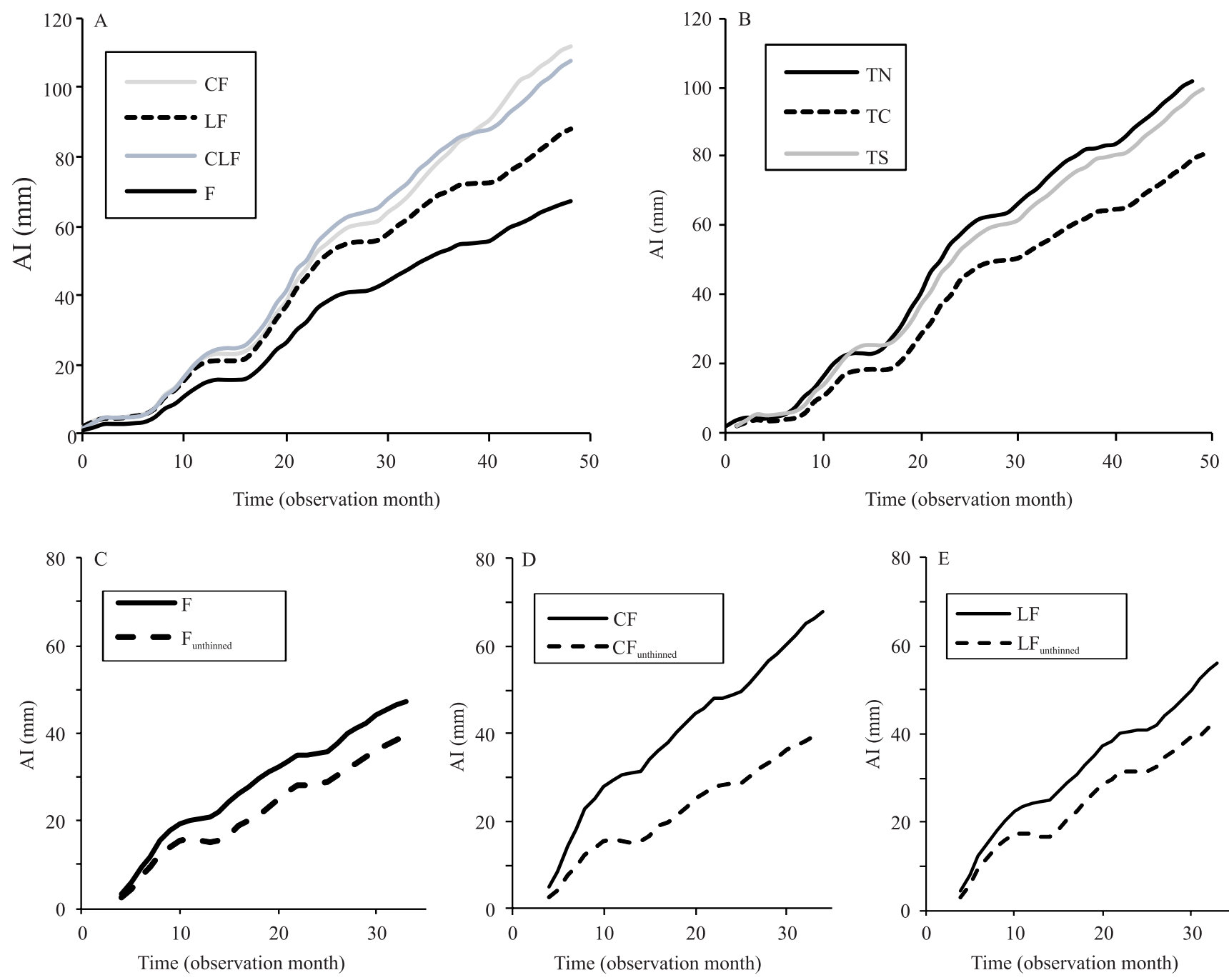

fertilization (Castro et al., 2017; Ferraz Filho et al., 2018). Thinning led to stem diameter growth, which was higher and lasted longer in CFL (Figure $2 \mathrm{C}, \mathrm{D}$, and $\mathrm{E}$ and Table 3). Furthermore, a great accumulated growth was verified in trees located in the sites where thinning was carried out, under all production systems.

The mean difference in accumulated increment between $\mathrm{CF}-\mathrm{CF}_{\text {unthinned }}$ and $\mathrm{LF}-\mathrm{LF}_{\text {unthinned }}$ was 15.3 and $7.8 \mathrm{~mm}$, respectively; and the mean annual rate increased by 61.6 and $33.0 \%$ respectively. Trees located in thinned sites, i.e., $\mathrm{F}-\mathrm{F}_{\text {unthinned }}$, showed the lowest

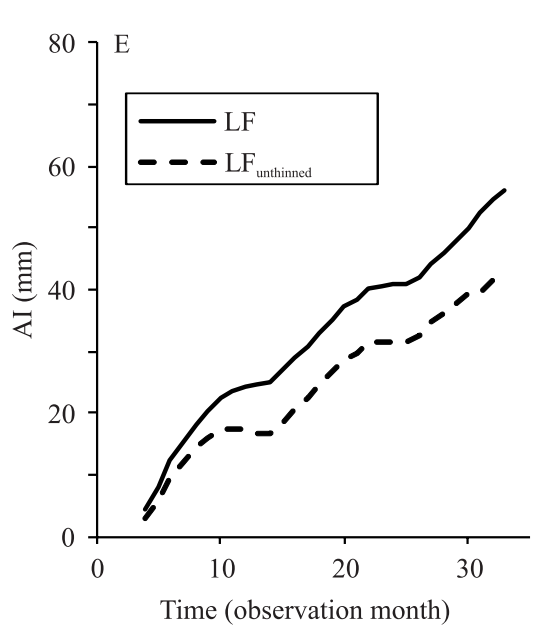

Figure 2. Accumulated increment in diameter (AI) per production system (A) due to eucalyptus (Eucalyptus grandis $\mathrm{x}$ Eucalyptus urophylla) tree position on the row and consequent sunlight exposure (B), in thinned and unthinned sites, under forest monoculture (C), crop-forestry (D), and livestock-forestry (E). Data collected from December 2016 to May 2019. CF, crop-forestry; LF, livestock-forestry; CLF, crop-livestock-forestry; F, forest monoculture; TN, trees exposed to sunlight to the north; TC, trees exposed to sunlight in the center; and TS, trees exposed to sunlight to the south. 
accumulated increment increase of $6.1 \mathrm{~mm}$, with a mean annual rate increase of $28.9 \%$.

Thinning improved CMI regardless of the season (Table 3), although it was a little higher in the dry season. However, the effect of thinning changed depending on the production system. In $\mathrm{CF}$, the gain increase reached $21.3 \%$, on average, in the rainy season, and $58 \%$, in the dry season. This effect was observed throughout all the thinning period, totaling 33 months. Gains in LF were lower than $13 \%$ in the rainy season in 2018/2019 and lower than $43 \%$ in the dry season in 2017. The gains reached 10.6 and $25 \%$ in the rainy and dry seasons, respectively, in $\mathrm{F}$ - these rates were significant up to 13 months after thinning.

Table 2. Mean monthly increment in diameter $(\mathrm{mm})$ based on eucalyptus (Eucalyptus grandis x Eucalyptus urophylla) tree position (exposure to sunlight) in the row and season ${ }^{(1)}$.

\begin{tabular}{lcrrr}
\hline \multirow{2}{*}{ Year } & Season $^{(2)}$ & \multicolumn{3}{c}{ Tree position in the row } \\
\cline { 3 - 5 } & & \multicolumn{1}{c}{ TN } & \multicolumn{1}{c}{ TS } & \multicolumn{1}{c}{ TC } \\
\hline 2015 & Dry & $0.7 \mathrm{a} \mathrm{b} \pm 0.19$ & $0.6 \mathrm{~b} \pm 0.26$ & $1.0 \mathrm{a} \pm 0.24$ \\
$2015 / 2016$ & Rainy & $2.5 \mathrm{a} \pm 0.70$ & $2.6 \mathrm{a} \pm 0.24$ & $2.1 \mathrm{a} \pm 0.33$ \\
2016 & Dry & $1.2 \mathrm{a} \pm 0.46$ & $1.3 \mathrm{a} \pm 0.56$ & $0.7 \mathrm{~b} \pm 0.26$ \\
$2016 / 2017$ & Rainy & $4.5 \mathrm{a} \pm 0.61$ & $3.8 \mathrm{~b} \pm 0.55$ & $4.0 \mathrm{a} \mathrm{b} \pm 0.63$ \\
2017 & Dry & $1.6 \mathrm{a} \pm 0.50$ & $1.5 \mathrm{a} \pm 0.41$ & $1.1 \mathrm{a} \pm 0.62$ \\
$2017 / 2018$ & Rainy & $2.5 \mathrm{a} \pm 0.28$ & $1.7 \mathrm{~b} \pm 0.34$ & $2.4 \mathrm{a} \pm 0.51$ \\
2018 & Dry & $1.2 \mathrm{a} \pm 0.37$ & $1.4 \mathrm{a} \pm 0.43$ & $0.8 \mathrm{~b} \pm 0.19$ \\
$2018 / 2019$ & Rainy & $2.5 \mathrm{a} \pm 0.39$ & $2.1 \mathrm{a} \pm 0.36$ & $2.2 \mathrm{a} \pm 0.32$ \\
\hline
\end{tabular}

${ }^{(1)}$ Means followed by equal letters, in the rows, do not differ from each other by Tukey's test, at $5 \%$ probability. ${ }^{(2)}$ Dry, dry season from June to August; and Rainy, rainy season from September to May. ${ }^{(3)} \mathrm{TN}$, trees exposed to sunlight to the north; TS, trees exposed to sunlight to the south; and TC, trees exposed to sunlight in the center.
Thinning decreases leaf area index, which resulted in a lower water stress and in an increased water efficiency to produce wood (Forrester et al., 2012; Gavinet et al., 2020). Changes in resource availability (light, water, and soil nutrients) influence crown processes, since light availability, foliar nitrogen, and photosynthetic activity are all closely related (Forrester et al., 2012).

The correlation between CMI and the climatic variables was significant (Table 4). The most significant correlations were positive, showing a 30-day delay. The variables minimum temperature, relative humidity (\%), and rainfall were selected as model predictors. Sette Junior et al. (2012) recorded a 28-day delay and correlations of 0.61 and 0.50 for rainfall and minimum temperature, respectively, in E. grandis grown in Itatinga, in the state of São Paulo, Brazil. These findings are similar to those recorded in the present research.

The best model was defined using the stepwise procedure with accumulated rainfall at its original value in a 300-day delay time, as follows:

$$
\mathrm{CMI}=0.716+0.010 \mathrm{P}-0.000011 \mathrm{P}^{2}
$$

where CMI is the current monthly increment in diameter and $\mathrm{P}$ is rainfall in the 30-day delay time.

This model was highly significant $(\mathrm{F}=43.09 ; 0.001)$ and explained the mean increment variation by $64 \%$; moreover, it recorded a high estimate standard error of $36 \%$, without estimate biases (Figure $3 \mathrm{~A}$ ). The CMI in CLF can be estimated by using a single equation; however, it differed from the model used to estimate growth in F (Table 5).

Table 3. Mean monthly increment in diameter $(\mathrm{mm})$ based on the location of eucalyptus (Eucalyptus grandis x Eucalyptus urophylla) trees in thinned or unthinned sites per production system, year, and season ${ }^{(1)}$.

\begin{tabular}{|c|c|c|c|c|c|c|c|}
\hline \multirow[t]{2}{*}{ Year } & \multirow[t]{2}{*}{ Season $^{(2)}$} & \multicolumn{6}{|c|}{ Mean \pm standard deviation of monthly increment in diameter $(\mathrm{mm})$} \\
\hline & & $\mathrm{CF}$ & $\mathrm{CF}_{\text {unthinned }}$ & LF & $\mathrm{LF}_{\text {unthinned }}$ & $\mathrm{F}$ & $F_{\text {unthinned }}$ \\
\hline 2017 & Rainy & $4.6 \mathrm{a} \pm 0.49$ & $2.9 \mathrm{~b} \pm 0.97$ & $3.2 \mathrm{a} \pm 1.01$ & $2.9 \mathrm{a} \pm 0.97$ & $3.1 \mathrm{a} \pm 0.78$ & $2.5 \mathrm{~b} \pm 0.79$ \\
\hline 2017 & Dry & $1.5 \mathrm{a} \pm 0.43$ & $0.4 \mathrm{~b} \pm 0.40$ & $1.1 \mathrm{a} \pm 0.80$ & $0.3 \mathrm{~b} \pm 0.40$ & $1.0 \mathrm{a} \pm 0.24$ & $0.5 b \pm 0.17$ \\
\hline $2017 / 2018$ & Rainy & $2.2 \mathrm{a} \pm 0.51$ & $2.0 \mathrm{a} \pm 0.41$ & $2.0 \mathrm{a} \pm 0.39$ & $1.9 \mathrm{a} \pm 0.41$ & $1.8 \mathrm{a} \pm 0.22$ & $1.6 \mathrm{a} \pm 0.51$ \\
\hline 2018 & Dry & $1.2 \mathrm{a} \pm 0.38$ & $0.7 \mathrm{~b} \pm 0.23$ & $0.8 \mathrm{a} \pm 0.21$ & $0.7 \mathrm{a} \pm 0.23$ & $0.9 \mathrm{a} \pm 0.28$ & $0.9 \mathrm{a} \pm 0.28$ \\
\hline $2018 / 2019$ & Rainy & $2.2 \mathrm{a} \pm 0.42$ & $1.8 \mathrm{~b} \pm 0.42$ & $2.1 \mathrm{a} \pm 0.32$ & $1.5 \mathrm{~b} \pm 0.33$ & $1.4 \mathrm{a} \pm 0.36$ & $1.4 \mathrm{a} \pm 0.43$ \\
\hline
\end{tabular}

${ }^{(1)}$ Means followed by equal letters, in the rows, do not differ from each other by Tukey's test, at $5 \%$ probability. ${ }^{(2)}$ Dry, dry season from June to August; Rainy, rainy season from September to May. Production systems treatments: $\mathrm{CF}$, trees in thinning site under crop-forestry system; $\mathrm{CF}_{\text {unthinned }}$, trees in unthinning site under crop-forestry system; LF, trees in thinning site under livestock-forestry system; $L_{\text {unthinned }}$, trees in unthinning site under livestockforestry system; $\mathrm{F}$, trees in thinning site under forest monoculture; and $\mathrm{F}_{\text {unthinned, }}$, trees in unthinning site under forest monoculture. 
The behavior of CMI at rainfall time was parabolic, as it reached a maximum value of $2.9 \mathrm{~mm}$ in the integrated production systems and of $1.9 \mathrm{~mm}$ in the monoculture, with $475 \mathrm{~mm}$ accumulated rainfall within 30 days (Figure 3 B). The largest difference between the CMI curves in both systems was of 1.04 $\mathrm{mm}$, being observed at a rainfall range from 355 to 420 $\mathrm{mm}$. Such an accumulated rainfall is common in the assessed region in November and March.

Using rainfall in the model allowed explaining approximately $50 \%$ of CMI variation, which was higher than that in the model adopted by Castro et al. (2017). These authors used rainfall to model CMI due to rainfall, at $30 \%$ coefficient of determination. However, the observed linear behavior between the evaluated variables differed from the results recorded in the present study.

The used model allowed concluding that both water shortage and excess reduce tree growth in diameter. The highest CMI point was observed at $475 \mathrm{~mm}$, starting to decrease after this value was reached. The lowest growth in diameter of $\leq 1.0 \mathrm{~mm}$ was verified when accumulated rainfall reached $30 \mathrm{~mm}$, and the highest growth in diameter of $3.0 \mathrm{~mm}$ was recorded when rainfall ranged from 445 to $475 \mathrm{~mm}$. However, CMI decreased after the rainfall range from 445 to $475 \mathrm{~mm}$ was exceeded, likely because soil water saturation influenced breathing by the roots, as well as their water and nutrient absorption (Castro et al., 2017).

Table 4. Pearson's correlation values recorded for monthly increment in the diameter of eucalyptus (Eucalyptus grandis $\mathrm{x}$ Eucalyptus urophylla) trees, with climatic variables evaluated in intervals from 15 to 45 days before the assessment of increment in diameter from May 2015 to May 2019.

\begin{tabular}{lccc}
\hline Variable $^{(1)}$ & \multicolumn{3}{c}{ Monthly increment in the diameter } \\
\cline { 2 - 4 } & 15 days & 30 days & 45 days \\
\hline $\mathrm{T}_{\text {mean }}\left({ }^{\circ} \mathrm{C}\right)$ & $-0.20^{*}$ & $-0.21^{*}$ & $-0.16^{*}$ \\
$\mathrm{~T}_{\max }\left({ }^{\circ} \mathrm{C}\right)$ & $-0.42^{*}$ & $-0.47^{*}$ & $-0.41^{*}$ \\
$\mathrm{~T}_{\min }\left({ }^{\circ} \mathrm{C}\right)$ & $0.51^{*}$ & $0.52^{*}$ & $0.52^{*}$ \\
$\mathrm{RH}(\%)$ & $0.55^{*}$ & $0.56^{*}$ & $0.53^{*}$ \\
$\mathrm{P}(\mathrm{mm})$ & $0.52^{*}$ & $0.55^{*}$ & $0.54^{*}$ \\
$\mathrm{R}_{\text {global }}\left(\mathrm{MJ} \mathrm{m}^{2} \mathrm{~d}^{-1}\right)$ & $-0.38^{*}$ & $-0.41^{*}$ & $-0.37^{*}$ \\
$\mathrm{~V}_{\text {mean }}\left(\mathrm{km} \mathrm{h}^{-1}\right)$ & $-0.34^{*}$ & $-0.37^{*}$ & $-0.31^{*}$ \\
\hline
\end{tabular}

${ }^{(1)} \mathrm{T}_{\text {mean }}$, mean temperature; $\mathrm{T}_{\max }$, mean maximum temperature; $\mathrm{T}_{\min }$, mean minimum temperature; $\mathrm{RH}$, mean relative humidity; $\mathrm{P}$, accumulated rainfall; $\mathrm{R}_{\text {global }}$, global radiation; and $\mathrm{V}_{\text {mean }}$, mean wind speed. *Significant by the $\mathrm{F}$-test, at $1 \%$ probability.
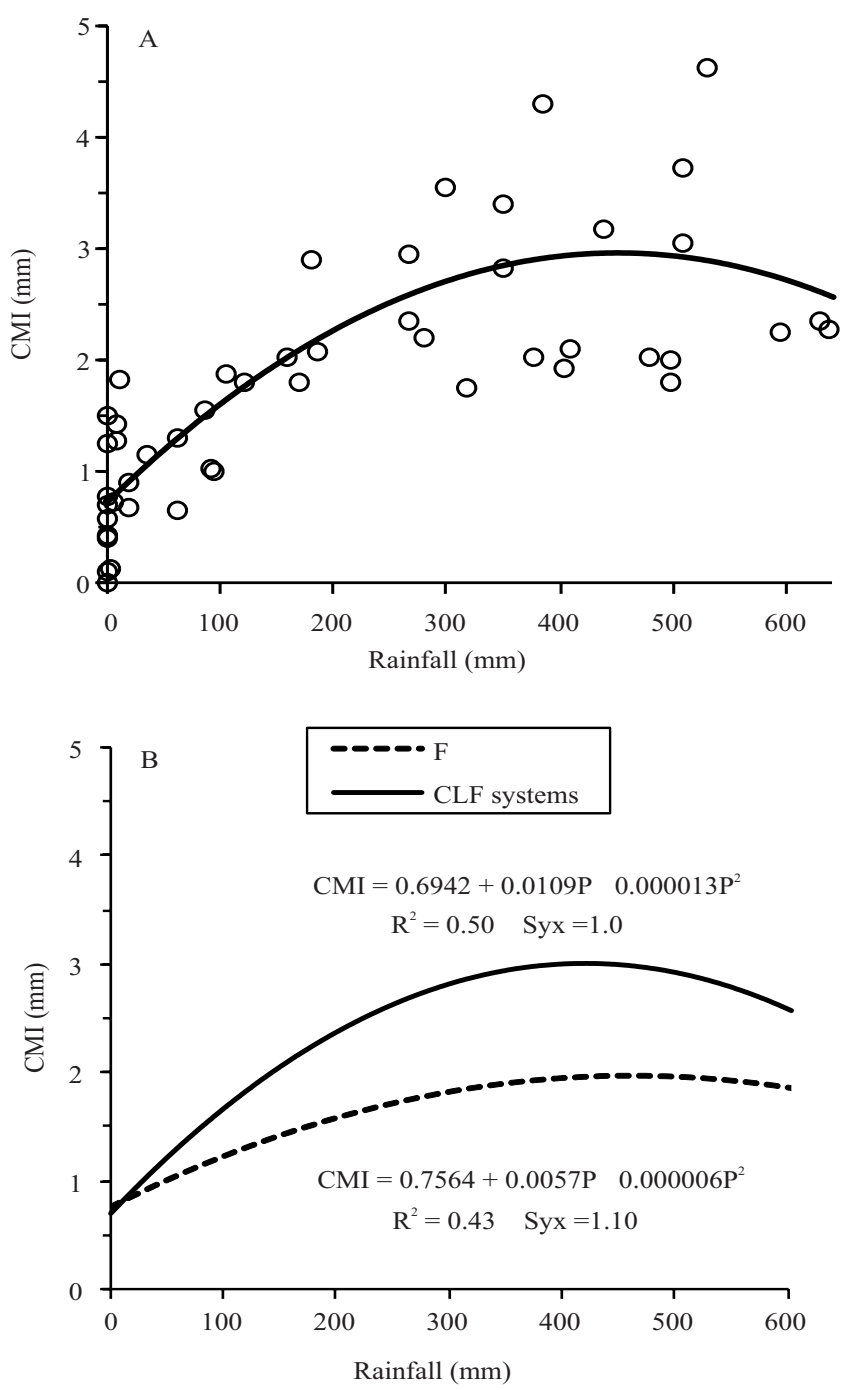

Figure 3. Estimated and observed current monthly increment in the diameter (CMI) of eucalyptus (Eucalyptus grandis $\mathrm{x}$ Eucalyptus urophylla), based on the accumulated rainfall within a 30-day delay period (A), as well as estimated and observed CMI based on rainfall and production system (B). Syx, standard error of the estimate.

Table 5. Results of the identity test based on the method proposed by Regazzi (1999).

\begin{tabular}{lclrc}
\hline Combination $^{(1)}$ & MS difference $^{(2)}$ & MS residue $^{(3)}$ & $\mathrm{F}_{\text {calc }}{ }^{(4)}$ & $\mathrm{F}_{\text {tab }}^{(5)}$ \\
\hline CLF CF LF F & 69.46211301 & $4,218.470633$ & 20.09 & 2.61 \\
CLF CF LF & 0.235352 & $2,074.695$ & 0.19 & 3.00 \\
CLF F & 42.39522278 & $1,751.003805$ & 37.19 & \\
CF F & 51.48371239 & $1,777.260764$ & 45.49 & 3.85 \\
LF F & 57.08079249 & $1,731.67751$ & 53.29 & \\
\hline
\end{tabular}

${ }^{(1)} \mathrm{CLF}$, crop-livestock-forestry; CF, crop-forestry; LF, livestock-forestry; and $\mathrm{F}$, forest monoculture. ${ }^{(2)}$ Mean square of the difference to test model identity hypothesis. ${ }^{(3)}$ Residual mean square to test model identity hypothesis. ${ }^{(4)} \mathrm{F}_{\text {calc }}$, calculated f-statistics. ${ }^{(5)} \mathrm{F}_{\text {tab }}$, table f-value, at $5 \%$ probability. 


\section{Conclusions}

1. The current monthly increment in the diameter of eucalyptus (Eucalyptus grandis $\mathrm{x}$ Eucalyptus urophylla) is seasonal and highly dependent on accumulated rainfall within a 30-day time delay, whereas the growth of tree diameter reduces both with water shortage and excess (minimum and maximum values of 30 and $475 \mathrm{~mm}$, respectively).

2. Trees under integrated production systems show a higher growth in diameter than those in monoculture, whereas the intercropping with soybean (Glycine max) and corn (Zea mays) leads to a greater growth in diameter than that with pasture.

3. Thinning accelerates the growth of the remaining trees, with a higher magnitude and longer duration under integrated systems.

\section{References}

ASSIS, P.C.R.; STONE, L.F.; MEDEIROS, J.C.; MADARI, B.E.; OLIVEIRA, J. de M.; WRUCK, F.J. Atributos físicos do solo em sistemas de integração lavoura-pecuária-floresta. Revista Brasileira de Engenharia Agrícola e Ambiental, v.19, p.309316, 2015. DOI: https://doi.org/10.1590/1807-1929/agriambi. v19n4p309-316.

BHERING, L.L. Rbio: a tool for biometric and statistical analysis using the $\mathrm{R}$ platform. Crop Breeding and Applied Biotechnology, v.17, p.187-190, 2017. DOI: https://doi.org/10.1590/1984-70332017v17n2s29.

CASTRO, V.R.; SURDI, P.G.; TOMAZELLO FILHO, M.; CHAIX, G.; LACLAU, J.P. Efeito da disponibilidade e da aplicação de potássio e sódio no crescimento em diâmetro do tronco de árvores de Eucalyptus grandis. Scientia Forestalis, v.45, p.89-99, 2017. DOI: https://doi.org/10.18671/scifor.v45n113.08.

DESLAURIERS, A.; ROSSI, S.; ANFODILlO, T. Dendrometer and intra-annual tree growth: What kind of information can be inferred? Dendrochronologia, v.25, p.113-124, 2007. DOI: https://doi.org/10.1016/j.dendro.2007.05.003.

DRAPER, N.; SMITH, H. Applied regression analysis. $3^{\text {rd }}$ ed. New York: John Wiley \& Sons, 1998. 736p.

DREW, D.M.; DOWNES, G.M.; GRZESKOWIAK, V.; NAIDOO, T. Differences in daily stem size variation and growth in two hybrid eucalypt clones. Trees, v.23, art.585, 2009. DOI: https://doi.org/10.1007/s00468-008-0303-y.

FERRAZ FILHO, A.C.; MOLA-YUDEGO, B.; GONZÁLEZOLABARRIA, J.R.; SCOLFORO, J.R.S. Thinning regimes and initial spacing for Eucalyptus plantations in Brazil. Anais da Academia Brasileira de Ciências, v.90, p.255-265, 2018. DOI: https://doi.org/10.1590/0001-3765201720150453.

FORRESTER, D.I.; COLLOPY, J.J.; BEADLE, C.L.; WARREN, C.R.; BAKER, T.G. Effect of thinning, pruning and nitrogen fertiliser application on transpiration, photosynthesis and wateruse efficiency in a young Eucalyptus nitens plantation. Forest Ecology and Management, v.266, p.286-300, 2012. DOI: https://doi.org/10.1016/j.foreco.2011.11.019.

FRANCHINI, J.C.; BALBINOT JUNIOR, A.A.; SICHIERI, F.R.; DEBIASI, H.; CONTE, O. Yield of soybean, pasture and wood in integrated crop-livestock-forest system in northwestern Paraná state, Brazil. Revista Ciência Agronômica, v.45, p.1006-1013, 2014. DOI: https://doi.org/10.1590/S1806-66902014000500016.

GAVINET, J.; OURCIVAL, J.-M.; GAUZERE, J.; GARCÍA de JALÓN, L.; LIMOUSIN, J.-M. Drought mitigation by thinning: benefits from the stem to the stand along 15 years of experimental rainfall exclusion in a holm oak coppice. Forest Ecology and Management, v.473, 118266, 2020. DOI: https://doi.org/10.1016/j. foreco.2020.118266.

GAZOLLA, P.R.; GUARESCHI, R.F.; PERIN, A.; PEREIRA, M.G.; ROSSI, C.Q. Frações da matéria orgânica do solo sob pastagem, sistema plantio direto e integração lavoura-pecuária. Semina: Ciências Agrárias, v.36, p.693-704, 2015. DOI: https://doi.org/10.5433/1679-0359.2015v36n2p693.

GONÇALVES, J.L. de M.; ALVAREZ, C.A.; HIGA, A.R.; SILVA, L.D.; ALFENAS, A.C.; STAHL, J.; FERRAZ, S.F. de B.; LIMA, W. de P.; BRANCALION, P.H.S.; HUBNER, A.; BOUILLET, J.P.D.; LACLAU, J.-P.; NOUVELLON, Y.; EPRON, D. Integrating genetic and silvicultural strategies to minimize abiotic and biotic constraints in Brazilian eucalypt plantations. Forest Ecology and Management, v.301, p.6-27, 2013 DOI: https://doi.org/10.1016/j. foreco.2012.12.030.

IBÁ. Indústria Brasileira de Árvores. Relatório Ibá 2020. Available at: <https://iba.org/datafiles/publicacoes/relatorios/ relatorio-iba-2020.pdf $>$. Accessed on: Apr. 72020.

ILPF em números. [Sinop: Embrapa Agrossilvipastoril, 2016]. $12 \mathrm{p}$.

MAGALHÃES, C.A.S.; PEDREIRA, B.C.; TONINI, H.; FARIAS NETO, A.L. Crop, livestock and forestry performance assessment under different production systems in the north of Mato Grosso, Brazil. Agroforestry Systems, v.93, p.2085-2096, 2019. DOI: https://doi.org/10.1007/s10457-018-0311-x.

MARTINS, E.G.; SHIMIZU, J.Y.; FERREIRA, C.A. Desempenho de procedências de grevílea em Quedas do Iguaçu, PR. Boletim de Pesquisa Florestal, n.40, p.45-56, 2000.

MATOS, E. da S.; CONCEIÇÃO, M.C.G. da; RODRIGUES, R. de A.R.; BIDONE, E.D.; CORDEIRO, R.C. Estoques de carbono do solo sob integração lavoura-pecuária-floresta. In: FARIAS NETO, A.L. de; NASCIMENTO, A.F. do; ROSSONI, A.L.; MAGALHÃES, C.A. de S.; ITUASSÚ, D.R.; HOOGERHEIDE, E.S.S.; IKEDA, F.S.; FERNANDES JUNIOR, F.; FARIA, G.R.; ISERNHAGEN, I.; VENDRUSCULO, L.G.; MORALES, M.M.; CARNEVALLI, R.A. (Ed.). Embrapa Agrossilvipastoril: primeiras contribuições para o desenvolvimento de uma agropecuária sustentável. Brasília: Embrapa, 2019. p.253-259.

MUGUNGA, C.P.; GILLER, K.E.; MOHREN, G.M.J. Treecrop interactions in maize-eucalypt woodlot systems in southern Rwanda. European Journal of Agronomy, v.86, p.78-86, 2017. DOI: https://doi.org/10.1016/j.eja.2017.03.004. 
OLIVEIRA, F.L.R. de; CABACINHA, C.D.; SANTOS, L.D.T.; BARROSO, D.G.; SANTOS JÚNIOR, A. dos; BRANT, M.C.; SAMPAIO, R.A. Crescimento inicial de eucalipto e acácia, em diferentes arranjos de integração lavoura-pecuária-floresta. Cerne, v.21, p.227-233, 2015. DOI: https://doi.org/10.1590/01047 760201521021489 .

PAULA, R.R.; REIS, G.G.; REIS, M.G.F.; OLIVEIRA NETO, S.N.; LEITE, H.G.; MELIDO, R.C.N.; LOPES, H.N.S.; SOUZA, F.C. Eucalypt growth in monoculture and silvopastoral systems with varied tree initial densities and spatial arrangements. Agroforest Systems, v.87, p.1295-1307, 2013. DOI: https://doi.org/10.1007/s10457-013-9638-5.

PRETZSCH, H. Density and growth of forest stands revisited. Effect of the temporal scale of observation, site quality, and thinning. Forest Ecology and Management, v.460, 117879, 2020. DOI: https://doi.org/10.1016/j.foreco.2020.117879.

REGAZZI, A.J. Teste para verificar a identidade de modelos de regressão e a igualdade de parâmetros no caso de dados de delineamentos experimentais. Ceres, v.46, p.383-409, 1999.

SETTE JUNIOR, C.R.; TOMAZELO FILHO, M.; LOUSADA, J.L.; LACLAU, J.P. Sazonalidade do incremento em diâmetro do tronco de árvores de Eucalyptus grandis pelo uso de dendrômetros. Ciência Florestal, v.22, p.763-775, 2012. DOI: https://doi.org/10.5902/198050987557.
SOIL SURVEY STAFF. Keys to soil taxonomy. $12^{\text {th }}$ ed. Washington: USDA, 2014.

SOUZA, A.P. de; MOTA, L.L. da; ZAMADEI, T.; MARTIM, C.C.; ALMEIDA, F.T. de; PAULINO, J. Classificação climática e balanço hídrico climatológico no estado de Mato Grosso. Nativa, v.1, p.34-43, 2013. DOI: https://doi.org/10.14583/2318-7670. v01n01a07.

TONINI, H.; MAGALHÃES, C.A. de S.; FARIA NETO, A.L. de. Technical thinning age of eucalyptus trees grown in crop-forest integration systems. Pesquisa Agropecuária Brasileira, v.54, e00648, 2019b. DOI: https://doi.org/10.1590/S1678-3921.pab2019. v54.00648.

TONINI, H.; MORALES, M.M.; SILVA, V.P. da; LULU, J.; FARIAS NETO, A.L. de. Efeito do sistema de plantio e da exposição solar sobre a alocação da biomassa no desenvolvimento inicial do Eucalipto. Ciência Florestal, v.29, p.86-95, 2019a. DOI: https://doi.org/10.5902/1980509817808.

VIANA, J.H.M.; SPERA, S.T.; MAGALHAES, C.A. de S.; CALDERANO, S.B. Caracterização dos solos do sítio experimental dos ensaios do Projeto Safrinha em Sinop - MT. Sete Lagoas: Embrapa Milho e Sorgo, 2015. 20p. (Embrapa Milho e Sorgo. Comunicado técnico, 210). 